\title{
DOME OF BAYT AL-MAL IN THE ISLAMIC MOSQUES: COMPARATIVE AND ARCHITECTURAL STUDY
}

| Received April 8 $8^{\text {th }}, 2019$ | Accepted February 19 ${ }^{\text {th }}, 2020$ | Available online June 15 $5^{\text {th }}, 2020$

DOI http://dx. doi. org/10.18860/jia.v6i1.6735 |

Mohammed Enab

ABSTRACT

Department of Islamic Archeology, Faculty of Archeology

Fayoum University

Fayoum, Egypt

maa25@fayoum.edu.eg

\begin{abstract}
Bayt al-mal is one of the important architectural innovations that characterized the Islamic civilization. It represents the treasury of the Islamic State, which preserves the various financial resources of the State. The Bayt al-mal appeared in the era of the Prophet Mohammed (peace be upon him), and its layout was simple reflects the simplicity of Islam. Its location was inside the mosque or adjacent to it. Bayt al-mal developed with the expansion of the Islamic State and the Islamic conquests, and it has a special called Diwan Bayt al-mal. Domes were built in mosques as one of the branches and sections of the Bayt al-mal. These domes were dedicated to preserving the different funds of the endowments and places. The location of these domes was in the great mosques' courtyard. They rise from the courtyard's surface and based on eight columns. These domes appeared especially in Umayyad mosques in Syria and Palestine. Then they spread in most countries in the east and west of the Islamic world. This research deals with the concept of the Bayt al-mal; its names, origin, architectural development, and the reasons to build them. This research also studies the dimension of jurisprudence in the building of these domes. It used an analytical study of the architectural shape of these domes and studies the impact of functional dimension on the form and plan of these domes. This study shows the remaining examples of these domes in Islamic mosques and mentions some examples of the extinct ones.
\end{abstract}

\section{KEYWORDS:}

Bayt al-mal; Treasury; Umayyad Mosque; Mosque of Hama; Mosque Amr lbn Al-Aas; Harran

\section{INTRODUCTION}

Bayt al-mal is considered as an important pillar of financial management in Islamic systems, where the money is considered to be one of the most important foundations for the countries during ancient times. With the establishment of the Islamic State during the reign of the Messenger, various financial resources began flowing to the Islamic State. Also, as it had various financial obligations that required to be spent on it either in a permanent or temporary form. This necessitated the existence of an architectural unit in order to preserve and manage these money funds. Bayt al-mal has emerged as an important institution since the Rashidian era, especially during the reign of the second caliph Omar bin Al-Khattab. This was due to the necessity required by the new situations of expansion in the Islamic conquests, and the influx of large amounts of money [1].

The word of Bayt al-mal consists of two-syllable words; the first, Bayt is an Arabic word meaning house, and the second is money. It is also an Arabic word meaning wealth. Ibn Manzur defines it as "what possessed of all things" [2][3]. So, Bayt al-mal is the house of money or the treasury of the State or the place designated to store money, whether private or public[4].

Bayt al-mal is also known as the treasury, which term is given to the place in which valuable things are stored. So, the treasury of money is intended for the building, place, or store in which the State's revenues are saved and spent on its various expenses and where the zakat funds are managed [5][6]. Bayt al-mal has developed over the subsequent Islamic eras and has become called on the authority, which is responsible for managing public money for Muslims. Also, it became the place where the public funds of the Islamic State are kept from various movables such as loyalty, fifths, spoils, and others until they are spent in its legal aspects. Finally, Bayt al-mal is known to be the institution that supervises all the money received and what comes out of it, and is spent in different aspects of expenditures. Now, Bayt al-mal is similar to the Ministry of Finance, and the responsible person of it is a minister of Finance [7].

The concept of Bayt al-mal has appeared since the days of the Prophet Mohamed as idea. The name of Bayt al-mal was not used in his reign Bayt al-mal as a standing institution was not present in the great era of the Prophet Mohamed . There was no urgent 
need for its existence because life was simple and uncomplicated, and money was scarce [8]. Despite that, some of the functions of Bayt al-mal were present, and its location was in the Prophet's house or one of the rooms of its women the companions' houses [9]. Bayt al-mal continued on this form during the reign of the Rashidian caliphs, where the form of Bayt al-mal was simple. It is just a simple room or several rooms that the caliph allocates from his home to keep the State's funds for a temporary period. In the era of Caliph Abu Bakr Al-Siddiq, the center of Bayt al-mal was in his house. Abu Bakr distributed what was in it directly. Then he took a separate building devoted to Bayt al-mal in Alsnh (a place in suburbs of Al- Madinah in Saudi Arabia). Then he transferred it to Al-Madinah. Several companions of the Prophet have taken command of the secretariat of Bayt al-mal, such as Abu Ubaidah Ibn al-Jarrah and Umar Ibn Al-Khattāb during the reign of Caliph Abu Bakr [8].

In the reign of Umar Ibn Al-Khattāb, the Islamic conquests expanded, and the spoils and money increased. In addition to the conquering, Muslims approached the Persian and Byzantine regimes in the territories that conquered them and got to know their civilization. As a result of that, the dawwa'in grew up, including Diwan of Bayt al-mal, which emerged as an independent institution with a centralized administration [10]. The Diwan of Bayt al-mal has become the central of it that based in Al-Madinah, the capital of the Islamic caliphate. Then the branches of it were found in different Islamic provinces. These branches consisted of treasuries, which mission is limited to depositing money with the State after spending from it, and then sending the rest to the headquarters of the central Bayt al-mal in the capital of the Islamic caliphate [11].

The establishment of Bayt al-mal in the Islamic States and cities were associated with the planning of these states. So, when Sa'd Ibn Abì Waqqās built the city of Al- Küfah, he placed the mosque and Dar Al'imart and placed Bayt al-mal between them. The mosque, Dar Al'imart, and Bayt al-mal were considered the main parts of the planning of different Islamic cities. Al- Madinah was the first example of this. This phenomenon became an architectural tradition in other cities during Islamic Caliphate [12]. Thus, it is clear that Bayt al-mal was an essential component in the planning of Islamic cities [13].

This research deals with the concept of the Bayt al-mal; its names, origin, architectural development, and the reasons to build them. This research also studies the dimension of jurisprudence in the building of these domes. The importance of this research lies in dealing with this distinctive architectural element that appeared in the courtyard of several Islamic mosques and spread to mosques with a Syrian influence. It has become a distinctive feature of Islamic architecture. The research aims to study the remaining models of these domes, explain them, know their architectural style, and its first emergence and the basic function they carry out.

\section{METHODS}

The research raises several important questions, including: Why were these domes established in the courtyard of the great mosques? Were these domes the main Bayt al-mal? The research also raises an important question about the reason for choosing the octagonal form in planning these domes.

Research methods used the inductive approach method by extrapolating what the historical sources mentioned about these domes, their functions, and the different roles.Also, the researcher relies on the comparative analytical approach through the descriptive study of the remaining examples of these domes to determine their distinctive architectural style and the origin of this style

\section{DISCUSSION}

\section{BAYT AL-MAL IN MOSQUES}

The idea of putting money into mosques has started since the era of the Prophet ; ; considered the safest place of Bayt al-mal. It was mentioned that the Prophet sprinkled and divided the money inside his mosque in Al- Madinnah. Imam Al- Bukhari narrated that the Prophet was collecting and distributing money in the mosque The historical evidence indicates that the Caliph Umar Ibn Al-Khattāb transferred Bayt al-mal to the mosque. His worker on Bayt al-mal Abd Allah Ibn Al-Arqam Al-Zuhri said to Caliph Umar, "Should we put this money in Bayt al-mal until we divide it?" But Caliph Umar said, "Do not make it in Bayt al-mal until we divide it". Then he placed it in the roof of the mosque, and they guarded it [8].

As previously mentioned, the location of Bayt almal in the era of Sa' 'd Ibn Abī Waqqās on Al- Küfah at 17 A.H was between the mosque and Dar Al'imart. It posed a danger to it and made it vulnerable to looting and theft. So, Sa'd wrote to the Caliph Umar describing to him the location of his house and the Bayt al-mal from the mosque. So Umar ordered him to move the mosque until it will be next to the house, and make the Dar in the Qiblah wall of the mosque. This conclusion is from this narration that Bayt al-mal was outside the northern wall of Dar Al'imart and when Caliph Umar wrote to Sa 'd and ordered him to expand the mosque and make its southern wall close to the northern wall. So that Bayt al-mal becomes attached to the wall of the mosque. From here, we conclude that the location of Bayt al-mal became adjacent to the mosque and was close to Dar Al'imart [14]. It continued like that until it was transferred inside the mosque.

The purpose of making the Bayt al-mal part of the mosque or adjacent to it is a policy that the State of the caliphate followed in the territories and the Islamic states. The reason for this was the desire of the caliphate to make Bayt al-mal under the direct supervision 
and the permanent control inside the mosque to protect it from theft as the money preserved beside it is considered money of all Muslims [2]. So, the responsibility for securing it and guarding it becomes an obligation imposed on the shoulders of every Muslim. Also, the mosque at that time was not devoid of worshipers and scholars. Thus, it is safe from any danger or threat [15].

There were specific places were designated for saving money in mosques [15]. The orientalist Max Van Berchem (1863-1921A.D) recognized that during the Umayyad period, it was usually done to keep the money that was collected together in somewhere inside the mosque. They were often placed in the courtyard of the mosque. These places take the shape of high domes and are known as Domes of Bayt al-mal or Domes of the Treasury. These domes were carried on huge columns and had a door of iron and locks [16].

There is a question that arises: Are these domes located in the courtyard of the great mosque with small proportional size were used as a general Bayt almal for Muslims? And if the answer is no, then what was there domes function?

As previously, the historical sources agreed that the Muslims' Bayt al-mal was located adjacent to the mosque, then it was moved inside the mosque's interior in designated places. Its location was continued inside the mosque until the time of the Caliph Umar Ibn Al-Khattāb. Then he established an independent Diwan for Bayt al-mal. The researcher agrees that Bayt al-mal was already located in the courtyard of the mosques. But he differs about these domes were the main places of Bayt al-mal in the mosques since the beginning of Islam and he explains his opinion in the following reasons; The establishment of these domes in this architectural form in the mosque's courtyard has begun during the Umayyad period, which was characterized by Islamic expansions that spread from the far east to the far west. There also was an independent Diwan for Bayt al-mal, which has its independent administrative, regulatory, and security authority. The first model of these domes is the western dome of the Umayyad Mosque in Damascus, which was built in a late period during the era of the caliph Al-Walid Ibn Abd Al-Malik (86-96A.H/705715A.D). In fact that the distinctive architectural form of these domes raises another problem; they were designed with a distinctive architectural form to preserve important things to be safe from theft and plunder. So, the researcher raises several possibilities about the nature and function of these domes and why they are known as the domes of Bayt al-mal in the following points;

1. These domes were used to store money inside it, but a specific type of money. It was known that there were different types and divisions of Bayt almal. Some of them are specific for public money, which is also divided into different types. Another type is for the private money, and it is kept in specific places within the royal palaces and is known as (the private Bayt al-mal). We conclude from the previous presentation that these domes served as sub-Bayts belonging to the main Bayt al-mal, which were specific for a specific type of money[17].

2. These domes were used to save endowment funds and Waqfs money on these mosques [18]. This Waqf money used to spend for students who learn and study in these mosques. Also, they have been used to preserve the different written endowments and rare documents for these mosques [19]

In any case, the location of these domes and architectural design confirm that they were used as places to save important things that fear from theft and looting, and need for more protection and insurance. And indeed, these domes were also used to save important papers and manuscripts and also used as a treasury to save important books and documents and other precious things. They were sometimes used as a headquarters to keep records of the judges and their dawwa'in [20] while some consider that they were intended to deposit and keep the orphan's money [21]

\section{A DESCRIPTIVE STUDY OF THE REMAINING DOMES OF BAYT AL-MAL IN MOSQUES}

The domes of Bayt al-mal spread in most of the mosques of the Levant in Damascus, Aleppo, Homs, and others during the Umayyad era. Also, they appeared in other Umayyad mosques outside the Levant in Egypt and Morocco. Then they spread throughout the historical ages with a Syrian influence. The researcher will study the description of the remaining examples of these domes. And he will also deal with extinct examples of them from travelers' writings and historical resource books. There are only two remaining examples of domes of Bayt al-mal in mosques that is shown in Table 1

Table 1. Remaining examples of the domes of Bayt al-Mal (The Author)

\begin{tabular}{|c|c|c|c|c|}
\hline & Example & Location & Date & Notes \\
\hline 1. & $\begin{array}{l}\text { Dome of } \\
\text { Bayt al-mal } \\
\text { in the } \\
\text { Umayyad } \\
\text { Mosque in } \\
\text { Damascus }\end{array}$ & $\begin{array}{l}\text { In the court- } \\
\text { yard of the } \\
\text { Umayyad } \\
\text { Mosque in } \\
\text { Damascus }\end{array}$ & $\begin{array}{l}\text { The } \\
\text { Umayyad } \\
\text { period }\end{array}$ & $\begin{array}{l}\text { It is consid- } \\
\text { ered the first } \\
\text { example of } \\
\text { the domes of } \\
\text { Bayt al-mal }\end{array}$ \\
\hline 2 & $\begin{array}{l}\text { Dome of } \\
\text { Bayt al-mal } \\
\text { in the } \\
\text { great } \\
\text { Mosque, } \\
\text { Hama, } \\
\text { Syria }\end{array}$ & $\begin{array}{l}\text { In the court- } \\
\text { yard of the } \\
\text { Great } \\
\text { Mosque, } \\
\text { Hama, Syria. }\end{array}$ & $\begin{array}{l}\text { The Ab- } \\
\text { basid era }\end{array}$ & $\begin{array}{l}\text { It is similar to } \\
\text { the Umayyad } \\
\text { Mosque in } \\
\text { Damascus. }\end{array}$ \\
\hline
\end{tabular}

DOME OF BAYT AL-MAL IN THE UMAYYAD MOSQUE IN DAMASCUS

This dome is considered the oldest and most important of the domes in the courtyard of the Umayyad Mosque in Damascus. It is also known by the name Dome of Aisha. It is an octagonal dome similar to the fortified tower [22]. It has differed in its history, as 
some attributed it to the Umayyad era of the Caliph era Al-Walid Ibn Abd Al-Malik (86-96 AH/705-715 AD) and some refer it back to the Abbasid era to the governor Al-Fadl Ibn Ali Salih; the governor of Damascus by the Abbasid state 172AH/789AD [19]. The role of this dome was numerous; some saw that its primary function was Bayt al-mal, where the mosque's money was deposited in it [23][24]. But others see that the caliph Al-Walid Ibn Abd Al-Malik established it to preserve the books, manuscripts, and the endowments documents of the mosque [25]. When it was opened in 922 A.H/1516 C.D, it has already been found in it some rare papers and Qur'an written in Kufic script [26]. Also, when it was opened in the Ottoman period in 1306A.H/1888A.D, it has already been found in some Qurans, manuscripts, and some endowments documents, which were transferred to Istanbul [27] (Figure 1, 2)

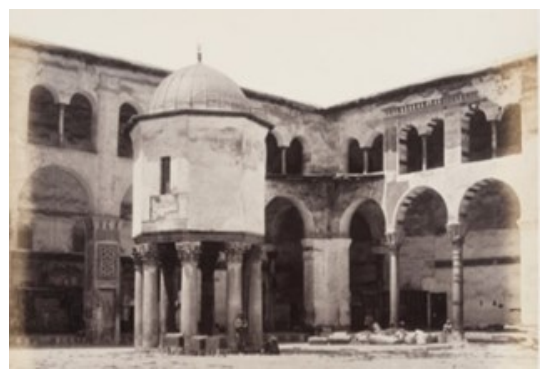

Figure 1: An archival image of the Umayyad Mosque during the $3 \mathrm{AH} / 9 \mathrm{AD}$ from the archive of Creswell indicates the dome of Bayt al-mal [29].

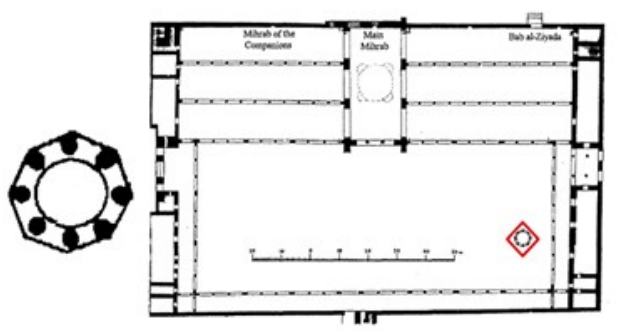

Figure 2: The plan of the Umayyad Mosque shows the location of the Dome of Bayt al-mal in the courtyard [28]

The dome is an octagonal room built of alternating courses of stones and bricks. This method of building was an ancient Roman method. The dome is standing on eight columns with Corinthian capitals and is topped by a decorative cornice [28]. The area around the columns uses a water basin in the middle used as ablution. It is covered by a spherical dome covered with lead plates. The entrance of the dome is located on the northwestern side. It is a square entrance and is accessible by a moving staircase. It is about 4.63 meters high from the floor level to the dome entrance and about $9.95 \mathrm{~m}$ to the dome top [30]. The walls of the room were decorated with floral decorations and drawings of the buildings executed with golden mosaics and colored dyes (figure 3 ).

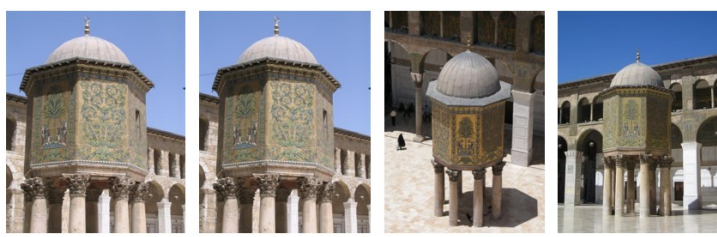

Figure 3: General view of the dome of Bayt al-mal in the courtyard of the Umayyad Mosque [29]

DOME OF BAYT AL-MAL IN THE GREAT MOSQUE, HAMA, SYRIA

The Great Mosque of Hama is considered to be one of the largest and oldest mosques in Hama, Syria [31]. It is located in the highest market in the Al-Medina district. The origin of the mosque was a pagan temple, like most buildings of Syria during the Roman period. Then it was transformed into a church in the Byzantine era. Finally, it was transformed into then a mosque by the great companion Abu Ubaidah Ibn Al-Jarrah, who opened the city of Hama in 17AH/638AD. The mosque witnessed innovations during the later ages. The most important of these innovations took place during the era of the Abbasid Caliph Al-Mahdi. The dome of Bayt al-mal in this mosque is likely considered one of its renovations. This dome is located on the courtyard of the mosque [32]. It is similar to the existing dome of Bayt al-mal in the Umayyad Mosque in Damascus (Figure 4, 5, 6)
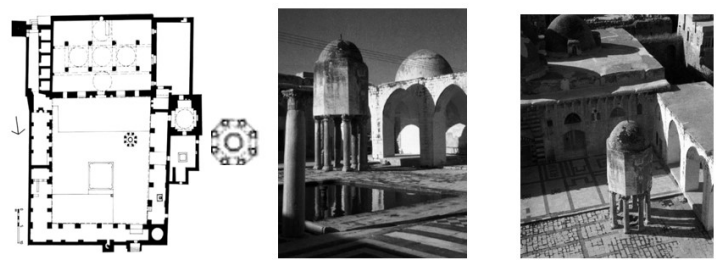

\section{Figure 4: Plan of the Great Mosque of Hama and the Dome of Bayt al- mal [33].}

\section{Figure 5: An archiv- al image of the Dome of Bayt al- mal in the Great Mosque of Hama from the archive of Creswell [29]}

\begin{abstract}
An archiv al image of the Dome of Bayt almal in the Great Mosque of Hama from the top, the archive of Creswell
\end{abstract} [29]

This dome built from bricks and stone. It consists of a high room that takes the octagon shape. It is covered by a dome which is standing on eight columns of limestone with very rich Corinthian capitals. This dome was designed in the same shape of Bayt al-mal in the Umayyad Mosque in Damascus. However, it is smaller in size and devoid of decorations. Some of the texts, decrees, and Sultan orders have been inscribed on these columns, which date back to various eras [16] (Figure 7, 8, 9). 

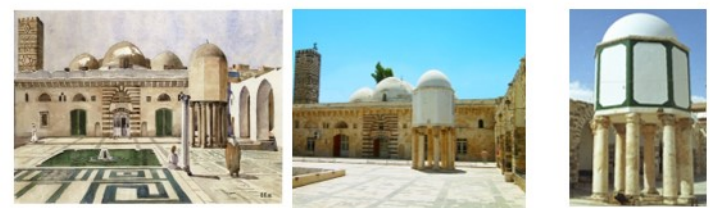

Figure 7: A photograph of one of the Orientalists photographers shows the courtyard of the Dome of Bayt al

- mal [34].
Figure 8: General view of the courtyard of Hama

Mosque and the Dome of Bayt almal [34].

\section{THE EXTINCT EXAMPLE OF BAYT AL-MAL IN MOSQUES}

There are extinct examples of Bayt al-mal in mosques, which date back to different historical eras. The researcher will mention the most famous of these examples, which were indicated in historical sources and travelers' books. Through them, we could recog nize the architectural form of these domes (Table 2).

Table 2. Famous extinct examples of the domes of Bayt al-Mal. (Author)

\begin{tabular}{|c|c|c|c|c|}
\hline & Example & Location & Date & Notes \\
\hline 1 & $\begin{array}{l}\text { Dome of } \\
\text { Bayt al- } \\
\text { mal in the } \\
\text { Mosque } \\
\text { of Amr } \\
\text { Ibn Al-Aas } \\
\text { in Cairo }\end{array}$ & $\begin{array}{l}\text { In the court- } \\
\text { yard of the } \\
\text { Mosque of } \\
\text { Amr Ibn Al- } \\
\text { Aas in Cairo }\end{array}$ & $\begin{array}{l}\text { The } \\
\text { Umayyad } \\
\text { period }\end{array}$ & $\begin{array}{l}\text { It was de- } \\
\text { stroyed and } \\
\text { replaced by } \\
\text { abulation } \\
\text { built by } \\
\text { Fatimid } \\
\text { caliph Al-Aziz } \\
\text { Billah }\end{array}$ \\
\hline 2 & $\begin{array}{l}\text { Dome of } \\
\text { Bayt al- } \\
\text { mal in the } \\
\text { Great } \\
\text { Mosque, } \\
\text { Harran, } \\
\text { Turkey. }\end{array}$ & $\begin{array}{l}\text { In the court- } \\
\text { yard of the } \\
\text { Great } \\
\text { Mosque, } \\
\text { Harran, } \\
\text { Turkey. }\end{array}$ & $\begin{array}{l}\text { The } \\
\text { Umayyad } \\
\text { period }\end{array}$ & $\begin{array}{l}\text { It is similar } \\
\text { to the Umay- } \\
\text { yad Mosque } \\
\text { in Damascus. }\end{array}$ \\
\hline 3 & $\begin{array}{l}\text { Dome of } \\
\text { Bayt al- } \\
\text { mal in the } \\
\text { Great } \\
\text { Mosque } \\
\text { of Córdo- } \\
\text { ba, Anda- } \\
\text { lusia }\end{array}$ & $\begin{array}{l}\text { In the court- } \\
\text { yard of the } \\
\text { Great } \\
\text { Mosque of } \\
\text { Córdoba, } \\
\text { Andalusia }\end{array}$ & $\begin{array}{l}\text { The } \\
\text { Umayyad } \\
\text { period }\end{array}$ & $\begin{array}{l}\text { The mosque } \\
\text { is fully ru- } \\
\text { ined. The } \\
\text { shape and } \\
\text { location of } \\
\text { the dome } \\
\text { are shown } \\
\text { on one of } \\
\text { the archive } \\
\text { pictures. }\end{array}$ \\
\hline 4 & $\begin{array}{l}\text { Dome of } \\
\text { Bayt al- } \\
\text { mal in the } \\
\text { Great } \\
\text { Mosque } \\
\text { of } \\
\text { Barda'a, } \\
\text { Azerbai- } \\
\text { jan [35] }\end{array}$ & $\begin{array}{l}\text { In the court- } \\
\text { yard of the } \\
\text { Great } \\
\text { Mosque of } \\
\text { Barda'a. }\end{array}$ & $\begin{array}{l}\text { The } \\
\text { Umayyad } \\
\text { period }\end{array}$ & $\begin{array}{l}\text { It was similar } \\
\text { to the Umay- } \\
\text { yad Mosque } \\
\text { in Damascus. }\end{array}$ \\
\hline
\end{tabular}

DOME OF BAYT AL-MAL IN THE MOSQUE OF ARM IBN ALAAS IN CAIRO

The historical sources indicate that the first construction of Dome of Bayt al-mal that was erected in Egypt was at the Mosque of Amr Ibn Al-Aas. They differed the first one who constructed this dome; some referred it to Qarah Ibn Shrek, the Emir of Egypt in 96AH/714AD [36], while most sources refer to Ibn Zayd Al-Tnukhid, who assumed the abscess of Egypt by the Umayyad caliph Suleiman Ibn Abd Al-Malik in 97AH/ 715 -716 AD. The ruler of Egypt was Abd al-Malik Ibn Rafa'ah Al-Fahmi and Muslims' money was deposited in it [17][20]. The traveler Ahmad Ibn Rustah saw this dome in the $3 \mathrm{AH}$ century, and he described it in his book Kitāb Al-A'lāk an-Nafisa that he was present in front of the pulpit. It consisted of a room surmounted by a dome based on stone columns. It was separated from the roof of the mosque. It could only be accessed through a wooden Qantarah that was dragged with ropes until its tip rested on the roof of the mosque, and it had an iron door with locks. It is clear from the description of Ibn Rustah that Dome of Bayt al-mal in the Mosque of Amr was in the Qiblah rewaq in front of the pulpit. However, it appears that it was transferred to facing rewaq to al Qiblah during $5^{\mathrm{AH}}$ century $/ 11^{\mathrm{AD}}$ century [37]. Dr. Suad Mahir believes that this Dome of Bayt al-mal is not the main Bayt al-mal of the State, but it was dedicated to Bayt al-mal of the orphans [21].

However, the assumption of the location of the Dome of Bayt al-mal inside one of the mosque Rewaqs is incorrect and does not coincide with the principles of the architectural design of the great mosques [38]. It never happened that the Dome of Bayt al-mal was placed inside the Rewaqs. Therefore, the most likely opinion is that the Dome of Bayt al-mal, which was constructed by Osama Ibn Zayd Al-Tnukhid, was located in the courtyard of the Mosque of Amr. It was similar to Domes of Bayt al-mal in the mosques of the Levant in its form and function. What confirms this view is that the Mosque of Amr is contemporary to the construction of the Umayyad Mosque [39]. Also, the ottoman traveler Evliya Çelebi states that he saw this dome, and it was located in the courtyard and consisted of an upper room Dedicated to Sufis sheikh Alaa Elddin Al-Ta'i [40] (Figure 10, 11).

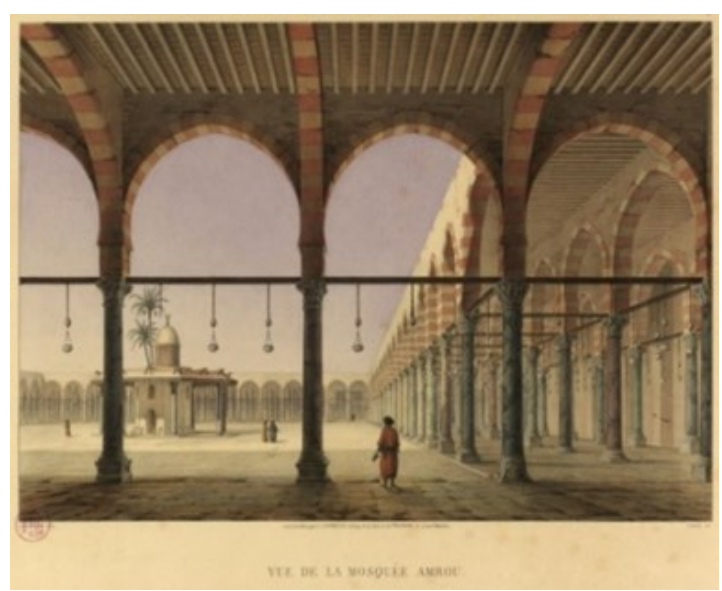

Figure 10: The courtyard of the Amr Mosque in Cairo, drawing by Pascal Coste [41]. 


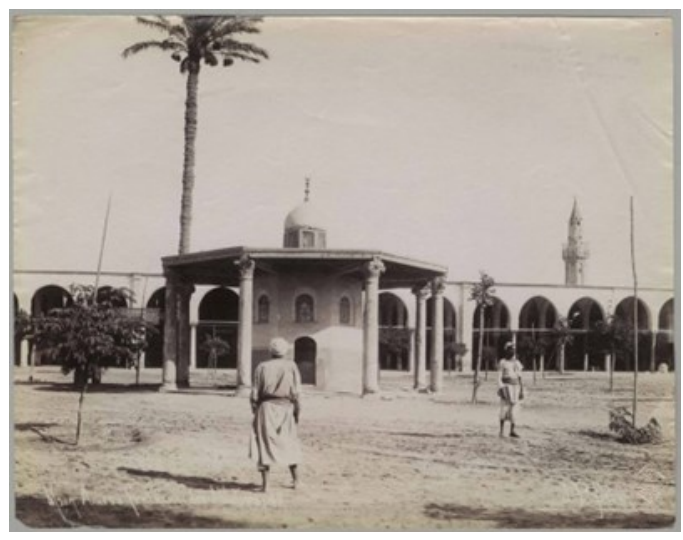

Figure 11: An archival photo of the dome in The courtyard of the Amr Mosque in Cairo [41]

Dome of Bayt al-mal in the Mosque of Amr Ibn AlAas was an octagonal room. It is topped with a semicircular dome. This room rises above eight cylindrical columns of Corinthian capitals. It could only be reached by a moving ladder that is placed at its single door when it is necessary to enter it to take some money in it [38]. The location of Bayt al-mal continued in its same location in the Mosque of Amr Ibn Al-Aas during the Tulunid and Ikhshidi era. In the year 378AH/988AD; the Fatimid caliph Al-Aziz Billah ordered to build abulation under the dome of Bayt al-Mal in Rajab month in 379AH/989AD. Then Abbasid ruler Saleh Ibn Ali Ibn Abdullah Ibn Abbas increased it during the Abbāsid caliph Abu Al-Abbas Al-Saffah [17]

\section{DOME OF BAYT AL-MAL IN THE GREAT MOSQUE, HARRAN}

Harran is a great city located in the south-east of Turkey. It was opened in the era of the caliph Umar Ibn Al-Khattāb [17]. It is considered to be the one of the famous Umayyad capitals, where the last Umayyad caliph Marawan Ibn Mohamed (127132A.H /744-750A.D) took it his capital. The Great Mosque of Harran is considered one of his most important architectural structures. It was built during the period in which caliph Marawan took Harran as the capital of the Umayyad caliphate. This mosque is also known as Al-Firdous Mosque. Unfortunately, it is dilapidated, and there are only some remaining arches and stone columns[39] (Figure 12). Excavations revealed some of the remains of this mosque. It is inferred from these excavations that this mosque occupied a square area. The Qiblah wall was about 100 meters [42][43]. The courtyard of the mosque had three domes, just like the domes in the Umayyad Mosque in Damascus. The most important of these domes was the dome of Bayt al-Mal, which was approximately mediated by the mosque courtyard.

This dome was similar in its architectural form to the dome of Bayt al-mal of the Umayyad Mosque in Damascus. It was an octagonal basin topped by a domed chamber based on eight columns with Corinthian capitals. There was a well of water and a basin for ablution underneath it. The main function of this dome was to Bayt al-mal, which was used to store money and the endowments inside it [44]. It was also later used as a warehouse for military equipment [19] (Figure 13

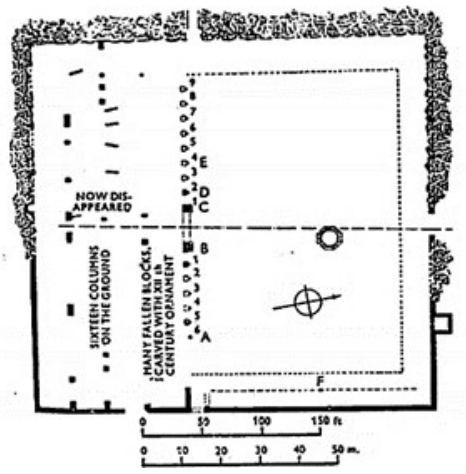

Figure 12: The plan of the Harran Mosque shows the location of the Dome of Bayt al-mal in the courtyard [44]

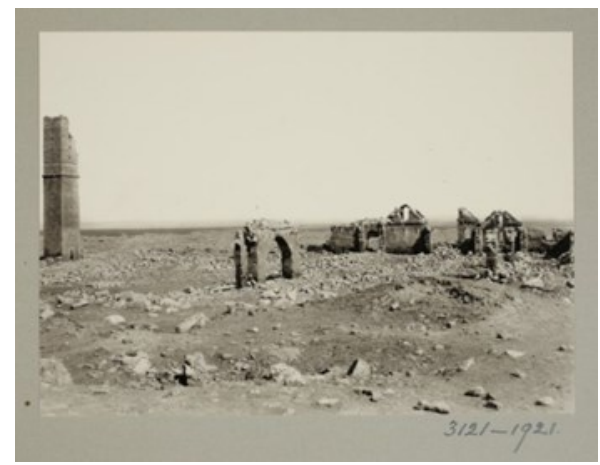

Figure 13: General view of the remaining parts of the Harran Mosque [44]

\section{DOME OF BAYT AL-MAL IN THE MOSQUES OF THE WESTERN ISLAMIC WORLD}

The Dome of Bayt al-mal in mosques of Morocco and Andalusia was influenced by Domes of Bayt al-mal in its architectural form. Indeed, the Islamic civilization in Morocco and Andalusia knew Bayt al-mal. It was like Bayt al-mal in the eastern cities. It also located in the mosque to preserve it and for its special status in the Caliphs era of the Umayyad caliphate in Andalusia [45].

In Morocco, the mosques were famous for the existence of Bayt al-mal. It was known by warehouses (in Arabic=Almustwde') [46]. It is a place similar to the treasury, in which precious things are preserved like endowments of the mosques, funds of orphans, inheritances, and others. The reason for building these warehouses was the abundance of endowments of the mosques, which became competing with the treasury of the State itself. They required more protection from the officials on the funds saved in it. And therefore, administrative and supervisory authority was formed to supervise and oversee those warehouses. It shows how far these private warehouses have had a legitimate political position embodied in its administrative and supervisory authority, emphasizing its sanctity and its

18 | Journal of Islamic Architecture, 6[1] June 2020 
importance. The warehouse of the Al-Qarawiyyin Mosque in Fez (580A.H/1184A.D) is considered the most famous example of these warehouses in Morocco. This warehouse was located under the rewaq in the north-eastern corner of the mosque, in which it was built after the Abu Annan library. There was another warehouse in Al-Qarawiyyin Mosque in Fez, which is known by Alhury. It was a skillfully built hall that had two openings for ventilation, and it also had two doors. Each door had three keys; each key was assigned to an agent separately, and the warehouse was not opened except in the presence of the three. Waqf funds were placed in the warehouse in large boxes with locks, and merchants also deposited their money in this warehouse [47].

In Andalusia, the concept of Bayt al-mal had a specific meaning, as it was responsible for the revenues of the endowments. It was completely separated from the public treasury of the State. The judge used to supervise its administration, and money that was kept in a Maqsura located mostly in the mosque courtyard, as in the Great Mosque of Córdoba. The historian Ibn Adhari reminds that the Prince AlMundhir Ibn Mohamed Ibn Abd El- Rahman Ibn AlHakam Ibn Hisham Ibn Abd Al-Rahman Ibn Mu'awiya built the Dome of Bayt al-mal at the end of the mosque courtyard of Córdoba, within the works of repair and renovation at the Mosque between (273275A.H/886-888A.D). This dome was subjected to a robbery during the reign of his successor grandson AlHakm Al-Mustansir Ibn Amir Al-Mu'minin Abd AlRahman Al-Nasir [45]. This dome was similar in its architectural form Domes of Bayt al-mal in the mosques of Damascus, Hama, and Homs [48]. This dome is considered a great manifestation of the influence of the Umayyad Mosque in Damascus on the Mosque of Córdoba. The construction of these warehouses has spread greatly during the Marinid period, especially during the reign of Sultan Abu Annan Faris Al-Marini (749-759A.H/1348-1357A.D). It is what we discern from the testimony of Ibn Al-Hajj AlNumayri Al-Gharnati -One of the writers of Sultan Abu Annan Fares- in his saying "His generous look required that it be written to all countries and regions under his high authority, by building warehouses adjacent to Buildings"[49].

\section{THE ANALYTICAL STUDY OF THE DOMES OF BAYT AL-MAL IN THE MOSQUES}

Ideal with several elements, $A$. the impact of the juristic and functional dimension on the architectural form of these domes. B. an analytical study of the architectural style of these domes and its origin. C. a study of the architectural and decorative elements of them.
THE IMPACT OF THE JURISTIC AND FUNCTIONAL DIMENSION ON THE ARCHITECTURAL FORM OF THESE DOMES

The juristic and functional dimensions were largely reflected in the shape and location and design of these domes. Due to what these domes in which endowment funds and money are kept require insurance. So, they were constructed in mosques to safeguard them from theft and increased emphasis on their sanctity. They confirm that the sanctity of the attack upon the sanctity of the mosque itself. The various jurisprudential rulings explained the prohibition of public money and the necessity of maintaining it. Building these domes in the middle of the mosque courtyard makes it visible in front of the people who do not stop going to the mosque from dawn to evening. Also, the idea of raising them above the ground columns increases the chances of protecting them and revealing who is trying to reach those [15].

Also, the functional dimension of these domes was reflected in its architectural design. It came as a room above the floor of the mosque's courtyard. They were built on columns to achieve maximum protection and safety, as they were architectural units that keep the money and important things to be safe from theft. Also, they do not have a fixed ladder, but the upper room is reached by an unstable ladder that is placed when there is a need to open these domes by the person in charge of Bayt al-mal.

\section{AN ANALYTICAL STUDY OF THE ARCHITECTURAL STYLE OF THESE DOMES}

The general style of the dome of money in the mosques, was an octagonal building that consists of two stores; the first is open. It is surmounted by the second storey; it is an upper, closed, and secure room in which precious things were preserved. This room was covered by a dome. There is sometimes an abulation at the bottom of this dome where located mostly on the mosque's courtyard [19] (Figure 14). It is considered the beginning of its appearance during the Umayyad period. Other examples were influenced by it in countries, like in Dome of Bayt al-mal in the Mosque of Amr Ibn Al-Aas in Cairo and the Great Mosque of Córdoba as one of the obvious Syrian influences [48]
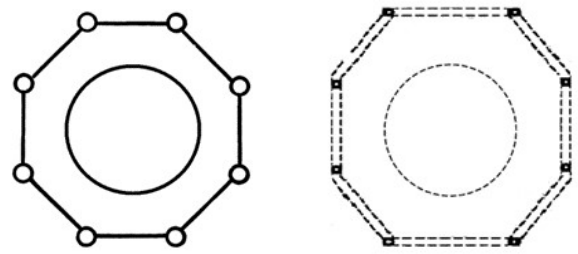

Figure 14: depicting the general form of the dome of Bayt al-mal in mosques (Author) 
The question arises why Domes of Bayt al-mal in mosques take octagonal shape. There are points of view of them; they perhaps built influenced by the Byzantine style, where they represented a continuation of the local old Syrian traditions. It came on the same Byzantine structures model that takes Octagonal shape, which widely spread in the Levant. Indeed The Octagonal form spread in plans of the memorial buildings, starting from the Hellenistic age in the countries of the Greeks. Then it moved to the planning of cities and ancient Roman buildings. After that, it was used for the Christian and Byzantine religious buildings in both Italy and the eastern colonies. So, it appeared clearly in the layout of the Byzantine churches that were existed in the Levant. Among the most famous examples, there are; the Cathedral of Bosra in Syria, which was built around the year 513A.D (Figure 15). The octagonal form was also used in several churches in Palestine, such as; the Ascension Church, which was constructed before 378 A.D and Maryam's tomb in Jerusalem [38]. In the Islamic era, the Umayyad caliph Abd Al-Malik Ibn Marwan was influenced by this form. He built the Dome of the Rock 72AH / 691AD on this layout with a Byzantine influence. The dome of the Rock became the first distinctive example in Islamic architecture, which was built on the octagonal form [50]. So, the octagonal form has become one of the distinctive architectural forms for Muslim architecture. Also, it has great symbolism and sanctity.
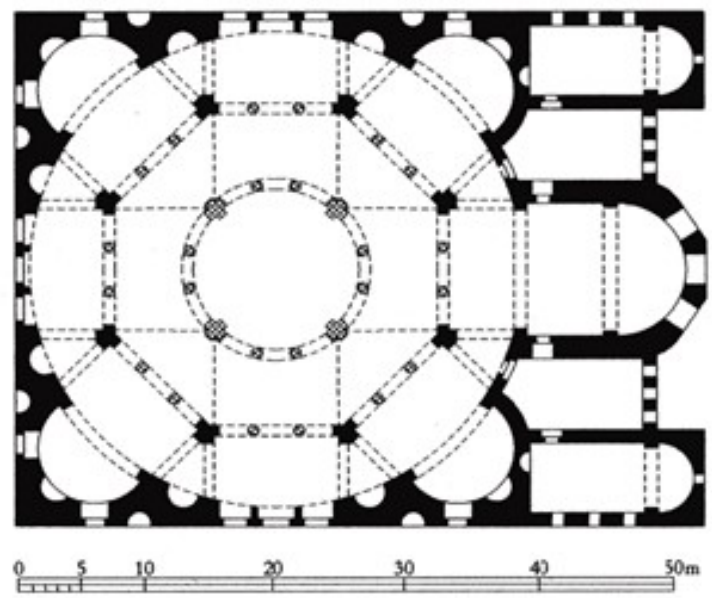

Figure 15: Plan of Cathedral of Bosra in Syria [38]

So, some see that the domes of Bayt al-mal were constructed as a model for the Dome of the Rock with its distinct octagonal layout. It is because a great standing and status of the Dome of the Rock are the hearts of Muslims. Therefore, the rulers of the Islamic states and provinces were keen that the domes of Bayt al-mal should be in the form of an octagon, and their location should be in the courtyard of the mosques to be visible to all worshipers [51] (Figure 16).

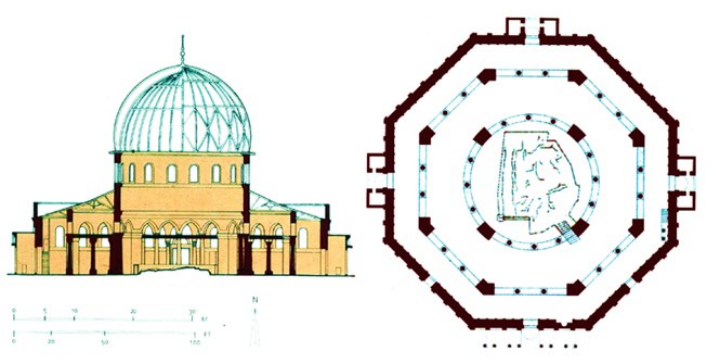

Figure 16: Plan of the Dome of the Rock

Another view of the reason for the choice the octagonal form in the layout of the dome of Bayt al-mal; perhaps the reason is religious jurisprudential. Where the Muslim architects represented by eight external facades of these domes on the allocated eight categories of eligible for charity as stated in the Quranic verse (60) of Surah At-Tawbah, Al-Qur'an al-Kareem; "AsSadaqat (i.e., Zakah) are only for the Fuqara', and AlMasakin and those employed to collect (the funds); and to attract the hearts of those who have been inclined (towards Islam) and to free the captives; and for those in debt; and for Allah's cause, and Ibn As-Sabil; a duty imposed by Allah. And Allah is All-Knower, All-Wise".

\section{A STUDY OF THE ARCHITECTURAL AND DECORATIVE ELEMENTS OF THE DOMES OF BAYT AL-MAL}

These varied elements were influenced by the Byzantine style. As for building materials, the stones were mainly used. And brick blocks were also used with the stone in the construction of the outer walls of the upper room of these domes, where the stone courses are exchanged with brick courses in horizontal rows (Figure 17). It is a well-known Roman method for building walls of different buildings [38]. This method was used in the construction of Islamic structures during the Umayyad era with a Byzantine influence as it increases the strength and durability of the building. Also, mortar and stucco were used in covering the outer and inner walls of this room
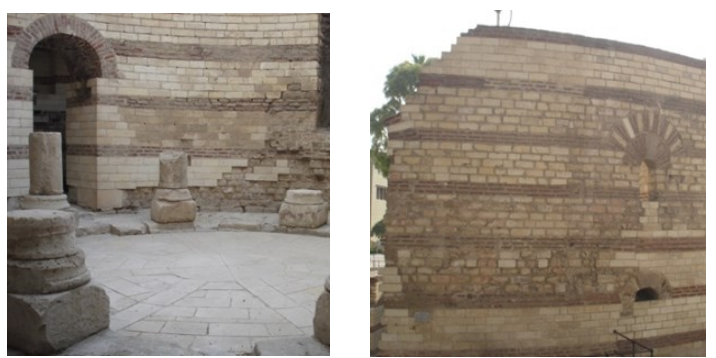

Figure 17: General view of the exchange of the stone courses and brick courses in the walls of the Babylon Fortress in Cairo (Author)

Elements of the ruins of the earlier buildings of the Roman and Byzantine styles were also used. It has appeared in the use of cylindrical stone columns of Corinthian capitals, which hold the upper room of the domes of Bayt al-mal. Also, it has appeared in the use 
of the oblique octagonal cornices, which surrounded the ends of the upper room walls. The purpose of these cornices was to protect the walls of these domes from rain and sunlight.

The dome is considered one of the most important architectural elements of the dome of Bayt al-mal. It is a shallow dome with a half-circular section. This dome is covered with either a layer of mortar as in the dome of Bayt al-mal in the great Mosque, Hama (Figure 19) or with plates of lead, as in the dome of Bayt al-mal in the Umayyad Mosque in Damascus (Figure 18). The purpose of these covering to protect the dome from various weather factors to keep the money and important manuscripts and Waqf documents preserved inside safe. Some of These domes were topped by the bronze bridle, which consists of two balls. It is based on a hemispherical base and is crowned with a crescent, such as in the dome of Bayt al-mal at the Umayyad Mosque in Damascus.

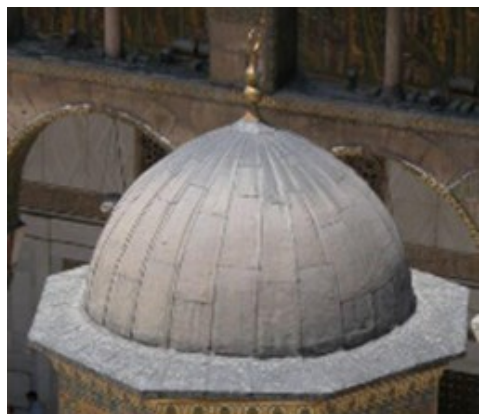

Figure 18: The octagonal cornice topped with a covering dome with plates of lead in the Umayyad Mosque in Damascus [29]

The dome of Bayt al-mal often has a single-window opening with a flat arch, which is considered the only door of the dome. It is accessed via ladder placed when needed to open it.
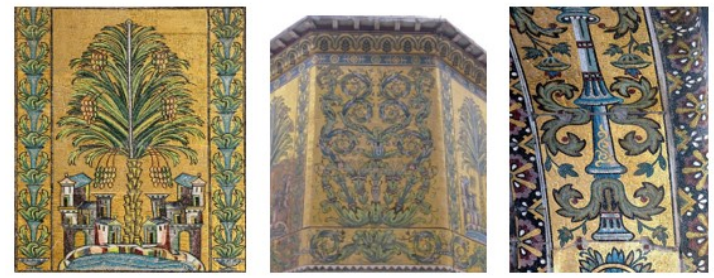

Figure 19: Gilded and colored mosaic decorations on the walls of the upper room in the Dome of Bayt al-mal in the Umayyad Mosque in Damascus [29]

The decorative elements of Bayt al-mal domes were very simple. They were devoid of any decorations, whether from the inside or the outside. They just were decorated with only a layer of mortar and stucco. We exclude from that the dome of Bayt almal in the Umayyad Mosque in Damascus, which was characterized by its rich decoration. The walls of the upper room of it are covered with gilded and colored mosaics executed according to the Byzantine style. Their decorative motifs are the same as the decorative motifs that decorate the walls of the Umayyad Mosque in Damascus; there are drawings of branches, plant leaves, palm trees, and building drawings (Figure 19).

\section{CONCLUSION}

The study dealt with Bayt al-mal and its development and has reached to several results;

1. The appearance of Bayt al-mal was from the time of the Messenger Mohamed. It shape was very simple. Bayt al-mal was distinguished by its proximity to the mosque and Dar Al'imart. Then it was transferred and became inside the mosque. The reason for attaching Bayt al-mal to the great mosques is to increase the assertion of its sanctity, to preserve it from looting, theft, and aggression, and also to ensure its survival. With the expansion of the Islamic State and establishing dawwa'in, Bayt al-mal was transferred outside the mosques in independent buildings that have an independent administrative authority with strict security.

2. The researcher presented the domes of Bayt almal in the mosques. The study proved that these domes weren't the main Bayt al-Mal. But it was used to preserve a specific type of money. Thus, they were considered sub-domes of Bayt al-Mal belonging to the central Bayt al-mal. Or, they were used to save Awqaf endowments for mosques, and therefore, it could be called the domes of money. They were also used alongside its primary function to preserve the important documents and manuscripts and Waqfs documents, and other things that are feared from loss.

3. The idea of establishing high domes dedicated to Bayt al-mal in the courtyard of the mosques is considered an original Syrian idea that dates back to the Umayyad era. These domes were spread in Umayyad mosques. Then these domes moved and appeared in mosques in the east and west of the world, with Syrian influence. These domes became one of the important architectural features that characterized the Islamic architecture.

4. These domes were characterized by a distinctive architectural form. They took the octagonal shape and consisted of an upper room that is based on eight columns. The explanation of the use of the octagonal shape in the design of these domes is that they were influenced by the Byzantine. Or they were constructed in the style of the dome of the Rock with its distinctive octagonal plan. Or perhaps the Muslim architects wanted by this octagonal shape to express the eight categories deserve charity.

5. The domes of Bayt al-mal were known in Morocco and Andalusia with a Syrian influence. They were known by the term warehouses (in Arabic=Almustwde'). They came in the same architectural form and designing Umayyad domes of Bayt al-mal. They located inside the mosques. There were used to preserve Waqf endowments inheritance funds, orphans, and others in them. 


\section{REFERENCES}

[1] A. I. S. Al-Halabi, "The Origin of Bayt Al-Mal in the Islamic State," the Arab Journal of Human Sciences, vol. 13, 1995.

[2] A. Ghalout and N. Mohammed, Jurisprudence of the General Resources of Bayt al Mal. Syria: Dar Abi Al-Fida International Group for Publishing, 2012.

[3] I. Manzoor, Lisan Alarab. Beirut-Lebanon: Dar Sader, 1405.

[4] I. R. Netton, Encyclopedia of Islam Civilization and Religion. London: Routledge, 2008.

[5] J. I Esposito, Dictionary of Islam. Oxford: Oxford University press, 2003.

[6] M. H. Rahman, "Bayt Al-Mal and Its Role in Economic Development: a Contemporary Study," Turkish Journal of Islamic Economics, vol. 2, no. 2, pp. 21-44, 2015

[7] A. Daruna, "The House of Money, Its Origination and Development from 1-4 AH," Islamic Awareness Magazine, kuwait, pp. 8-9, 2017.

[8] A. E.-B. M. H. Alwan, "Foundation of Bayt AlMal in the First Edition of Islam 1-132A.H," AlNajah National University, 2007.

[9] A. Adlan, Foundation of Bayt Al Mal in the Islamic System. Cairo: Egyptian Institute for Political and Strategic Studies, 2017.

[10] Al-Dhahabi, "Dual Al'iislam," in Investigation of Hassan Ismail Marwa, Mahmoud Arnaout, First Edit., Beirut-Lebanon: Dar Sader, 1999.

[11] I. A. Al-Hakam, Futuh Misr Wa'akhbaruha. Cairo: Library of Religious Culture, 1896.

[12] M. A. A.-S. Othman, "Islamic City," in World of Knowledge Series, Kuwait: National Council for Culture, Arts and Letters, 1988.

[13] K. Al-Janabi, Planning of Kufa City from Historical and Archeological Sources (especially the Umayyad Period). Baghdad: Dar Al-Gomhuriya Press, 1967.

[14] Al-Tabari, "Tarikh Al'umam Walmuluik Almaeruf Bitarikh Altabrii," in Investigation Abu Suhaib Al-Karmi, Amman: House of Ideas International.

[15] F. Shafei, Islamic Architecture: It's Past, Present and Contemporary. Saudi Arabia: KSU Publications, 1982.

[16] V. Berchem, Voyage en Syria. le Caire, 1914.

[17] Al-Maqrizi, "Almawaeiz Wal'iietbar Bidhikr Alkhutat Walathar Alshahir Bialkhutat Almaqriziati volume 4," in Investigation of Ayman Fouad Sayed, Cairo: Al-Furqan Foundation for Islamic Heritage, 2002.

[18] I. Battuta, Tuhfat Alnizar Fa Gharayib Al'Amsar Waeajayib Al'asfar Almsmat Rihlat Ibn Battuta. Beirut-Lebanon: Dar "lihya” Aleulwm, 1987.

[19] I. J. Al-Andalusi, Risalat Aietibar Alnaasik Fi
Dhakar Alathar Alkarimat Walmanasik Almashhur Birihlat Ibn Jubeir. Beirut-Lebanon: Publications of Dar Maktabat Alhlal, 1981.

[20] N. Osman, Structural Engineering of the Aleppo Mosques. Aleppo: Aleppo University Publications, 1992.

[21] S. Maher, Mosques of Egypt and Its Righteous Priorities. Cairo: General Authority for Culture Palaces, 2017.

[22] A. Gawad and T. Ahmed, Islamic Architecture, Thought and Civilization. Cairo: The AngloEgyptian Library, 1987

[23] E. Richard, O. Grapar, and M. Jenkins, Islamic Art and Architecture (650-1250AD). Abu Dhabi: Abu Dhabi Tourism and Culture Authority, 2012.

[24] H. Moanis, Mosques, World of Knowledge Series. kuwait: National Council for Culture, Arts and Letters, 1981.

[25] S. A.-D. Al-Munajjid, Damascus Mosque, Mentioned Something that Settled the Mosque Until 730 AH. Damascus, 1948.

[26] A.-B. Al-Damasqi, Nuzht Alanaam fi Mahasn Alsham. Cairo: Salafi printing press, 1923.

[27] A. Al-Tantawi, Umayyad Mosque in Damascus. Damascus: Government Press, 1960.

[28] A. Bahnassi, the Great Mosque of Sana'a. Paris: United Nations Educational, Scientific and Cultural Organization, UNESCO, 1988.

[29] P.-X. Coste, "Vue Intérieure De La Mosquée D’Amrou," V\&A's collections, 1922. [Online]. Available: http://collections.vam.ac.uk/item/ O170485/vue-interieure-de-la-mosqueewatercolour-coste-pascal-xavier/. [Accessed: 05-Jan-2019].

[30] Al-Maqdisi, 'Ahsan Altaqasim fi Maerifat Al'aqalim, 3rd Editio. Cairo: Madbouli Library, 1991.

[31] K. Shahāda, "Al-Jāmi‘al-a'lā al-kabīr fĩ Ḥamā," Les Annales Archaeologies Arabes Syriennes, vol. 26, pp. 213-222, 1976.

[32] A. Kaplony, the Haram of Jerusalem 324-1099 Temple, Friday Mosque, Area of Spiritual Power. Stuttgart: Steiner, 2002.

[33] M. Guidetti, In the Shadow of the Church: The Building of Mosques in Early Medieval Syria. Leiden: Brill, 2016.

[34] Namit Arora, "Hama and Environs," Shunya, 2000. [Online]. Available: http:// www.shunya.net/Pictures/Syria/hama/ Hama.htm. [Accessed: 15-Sep-2018].

[35] Al-Hamawi, Muejam Albuldan, 2nd Editio. Beirut-Lebanon: Dar Sader, 1995.

[36] I. Duqmaq, Al'intsar Luasitat Eaqd Al'amsari. Beirut-Lebanon: Publications of the Commercial Office for Printing and Publishing, 1891.

[37] H. Al Basha, Encyclopedia of Architecture, Archeology and Islamic Art, Vol.3, First Edit. Beirut -Lebanon: Oriental Papers, 1999. 
[38] F. Shafei, Arab Architecture in Islamic Egypt. Cairo: Egyptian General Book Organization, 1994.

[39] A. Petersen, Dictionary of Islamic Architecture. London: Routledge, 2002.

[40] O. Chalabi, "The Journey to Egypt, Sudan and the Land of Habash 1082-1091AH/16721680AD," in Investigation Hussein M. Al-Masri and others, Cairo: Dar Alafaq Alearabit, 2006.

[41] P. X. Coste, "Mosque of Amr ibn al-As," MIT Libraries, 1826. [Online]. Available: http:// dome.mit.edu/handle/1721.3/65833. [Accessed: 05-Jan-2019].

[42] A. Fikri, Cairo Mosques and Schools. Cairo: Dar Al Ma'arif, 1962.

[43] A. Kamel, Umayyads and Their Architectural Archeology in the Levant, Iraq, Hejaz, Yemen, Egypt and Africa. Cairo: Dar Alafaq Alearabit, 2002.

[44] K. Creswell, the First Islamic Antiquities. Damascus: Dar Qatabiya for Printing, 1984.

[45] I. 'Adhari Al-Marrakshi, Albayan Almaghrib Fi
'Akhbär Al'undalus Walmughrib, 3rd Editio. Beirut-Lebanon: Dar Althqaft, 1983.

[46] A. E. R. Ghaleb, Encyclopedia of Islamic Architecture Arabic-French-English. Beirut-Lebanon: Gros Press, 1988.

[47] A. H. Al-Tazi, Jamie AlQurwiayn, Al-Masjid and The Mosque in the City of Fez Encyclopedia of Its Architectural and Intellectual History, 2nd Editio. Morocco: Dar Nashr Almaerifa, 2000.

[48] A. S. Salem and A. Aziz, Cordoba, Present of the Islamic Caliphate. Alexandria: Foundation of Youth University, 1997.

[49] Al-Numeiri, Faid Al-Aabab and Wa'iifadat Qadah Aladab fi Alharakat Alsaeidat to Constantine and Al-Zab. Beirut-Lebanon: Dar Al-Gharb AlIslami, 1990.

[50] M. A. A.-S. Othman, "A New Theory of Explanation of How to Plan the Dome of the Rock," Journal of the Ages, vol. 3, no. 2, pp. 237-264, 1988.

[51] L. Nees, Perspectives on Early Islamic Art in Jerusalem, vol. 5. Leiden: Brill, 2016. 